the native softwoods in cut-over State forests, when the land is not suitable for farming. Experiments are being made with Kauri, the New Zealand valuable timber tree, "to test the practicability of working a Kauri forest on a sustained yield plan" and the possibility of re-establishing Kauri on tea-tree scrub lands which formerly carried Kauri forest. As regards indigenous hardwoods, the various species of southern beech (Nothofagus) are said to be quick growing. Beech forests are therefore to be managed for the production of future hardwood requirements.

The concluding paragraphs of the brochure sum up the opinions hold by the State Forest Department. It is pointed out that, after the naturally-grown forests of native trees have been cut over, there will be an end of the splendid wide and clean boards now being obtained, and that thence boards of natural timber will be mostly narrow and more or less knotty, such as the red and white Baltic deals exported to Great Britain (the writer must be confusing the Britishgrown material with that of the Baltic, which usually is free from knots). Secondly, it is anticipated that fabricated boards, etc., made from disintegrated wood will largely replace natural timber, and knotty timber can be used for the former without any serious difficulty. Thirdly, and in spite of the recognition by the Forest Department that they must eventually disappear, it is said that it will be apparent to all "that the remaining splendid stands of indigenous timber, which Nature has provided us, should be used with the greatest care and economy".

Attention has been directed (Nature, Feb. 14) to the private companies which have been formed in New
Zealand to promote afforestation work. Many of these companies have beon federated into an Association which represents a combined capital of $£ 5,000,000$. The objective of these companies is the ultimate afforestation of a million acres of exotics. It is recognised that this work to be done expeditiously is a purely business proposition, quite outside the capacity of a State Department, which could not be granted the funds from the public purse to carry it on with such rapidity.

As a result of the War, several of the European countries are making arrangements to increase their areas of coniferous softwoods. In France, for example, there are extensive stretches of very poor heather, etc., clad lands in the Plateau Central, for the afforestation of which an extensive propaganda is being carried on. Whilst the Government Forest Department is undertaking a certain amount of work, the aim is that the greater part of the afforestation work shall ultimately be done (with grants when necessary from the State) by the private proprietor and the village communities owning the land. But this recognition does not involve the sacrifice of her magnificent hardwood forests, chiefly of oak and beech, which have been under an increasingly fine management since the days when Colbert (1660) first ordered an investigation into the methods in force in the State forests.

With such examples before her, it would appear to be an irremediable disaster for New Zealand to sacrifice those of her fine indigenous forests still left, without an effort to save them, and the markets dependent upon them, for future generations.

\title{
The Mellon Institute.
}

N the occasion of the award of its medal to Messrs. A. W. Mellon and R. B. Mellon, the founders of the Mellon Institute of Industrial Research, Pittsburgh, U.S.A., the American Institute of Chemists has devoted an issue of its bulletin to an account of the inception and progress of the Institute. According to the Chemist for April, its foundation in 1913 was a direct result of the success of the inauguration of the industrial fellowship system in the University of Pittsburgh. Twenty years after the adoption by Dr. R. K. Duncan of this method of combining education with industrial profit there are in operation sixtyfour such fellowships, the work being conducted by 109 fellows and 31 assistants. The extent to which the value of the Institute as a servant to industry has been realised may be gauged by the fact that for ten years after its establishment, in accommodation believed to provide for future growth, the waiting list was almost as long as the list of companies whose problems were already boing investigated.

A new home, some three hundred feet square and eight stories high, and designed in the Ionic style, will be a notable monument to the economic success of industrial research and the esteem in which the organisation is held in a progressive industrial country.

The industrial research carried out by the Institute is organised on a contract basis. The problem is set by, and the results become the property of, the donor of the fellowship; the worker is found and engaged by the Institute and provided with the broadest facilities for a minimum period of one year. Only one investigation is carried out on a particular subject at any one time. The prosecution of fundamental scientific investigations is not neglected, funds being available for application to this essential precursor of industrial development. All questions of publication, patent protection, or advertisement aro determined by consultation with the donor, whilst all forms of co-operation which do not violate the necessary limits of confidential operation are encouraged.

The Institute stimulates the holders of fellowships to put forth their best efforts by affording both freedom and sustained support. Besides creating new industries and strengthening old ones it has thus produced a body of trained and practised investigators, who have played no small part in advancing the industrial position of the United States of America.

On its educational side, the Mellon Institute is worthy of special attention. The education which is afforded is not merely. scientific, but also social ; it is concerned with the personal and official duties of research staffs, with commercial procedure, with professional ethics, and with industrial psychology. The worker is trained to convey and interpret the results of his scientific work to the non-scientific business man in such a way that the latter can estimate its commercial value and appreciate its possibilities. The effort is being mado to raise the professional status of the research worker by encouraging the proper typo of man to engage in scientific professional work, and by improving his economic position. Equally important is the effect on the outlook of those entrusted with the direction of affairs, both in individual industries and in national and international trade.

The increasingly dominant position of science cannot be overlooked, and it becomes essential in the modern world that those who are given responsibility should also be equipped with knowledge. America is justly proud of the Mellon Institute; it is an institution which deserves the careful study of progressive nations.

No. 3227 , VoL. 128] 